\title{
Parasitism, community structure and biodiversity in intertidal ecosystems
}

\author{
K. N. MOURITSEN and R. POULIN* \\ Department of Zoology, University of Otago, P.O. Box 56, Dunedin, New Zealand
}

SUMMARY

There is mounting evidence that parasites can influence the composition and structure of natural animal communities. In spite of this, it is difficult to assess just how important parasitism is for community structure because very few studies have been designed specifically to address the role of parasites at the community level, no doubt because it is difficult to manipulate the abundance of parasites in field experiments. Here, we bring together a large amount of published information on parasitism in intertidal communities to highlight the potential influence of parasites on the structure and biodiversity of these communities. We first review the impact of metazoan parasites on the survival, reproduction, growth and behaviour of intertidal invertebrates, from both rocky shores and soft-sediment flats. Published evidence suggests that the impact of parasites on individuals is often severe, though their effects at the population level are dependent on prevalence and intensity of infection. We then put this information together in a discussion of the impact of parasitism at the community level. We emphasize two ways in which parasites can modify the structure of intertidal communities. First, the direct impact of parasites on the abundance of key host species can decrease the importance of these hosts in competition or predator-prey interactions with other species. Second, the indirect effects of parasites on the behaviour of their hosts, e.g. burrowing ability or spatial distribution within the intertidal zone, can cause changes to various features of the habitat for other intertidal species, leading to their greater settlement success or to their local disappearance. Our synthesis allows specific predictions to be made regarding the potential impact of parasites in certain intertidal systems, and suggests that parasites must be included in future community studies and food web models of intertidal ecosystems.

Key words: Altered behaviour, castration, food webs, host survival, rocky shores, soft-sediment flats, trematodes.

\section{INTRODUCTION}

Parasitism is now widely recognized as a factor that can influence the composition and structure of natural animal communities (Minchella \& Scott, 1991 ; Combes, 1996; Hudson \& Greenman, 1998; Poulin, 1999). The presence of certain species, or their abundance relative to that of other species in a community, may be entirely dependent on the action of parasites. In addition to the numerous studies that have shown that parasites can decrease the survival or reproductive output of their host, there is evidence that the outcome of interspecific competition between hosts (Hudson \& Greenman, 1998) and the interaction between predators and prey (Lafferty, 1999) can be modified by parasites. The latter effect often involves parasite-mediated changes in host behaviour that increase their probability of being captured by a predator; these changes, however, can also impact on communities in other ways (Poulin, 1999). Despite this accumulating evidence, it is still difficult to assess just how important parasitism is for community structure for at least two reasons. First, very few studies have been designed specifically to address the role of parasites at the community level. This is no doubt because it is difficult to manipulate the abundance of parasites in field experiments.

\footnotetext{
* Corresponding author: Tel: +643479 7983. Fax: +64 34797584 .

E-mail: robert.poulin@stonebow.otago.ac.nz
}

Second, the many studies with results that imply a role for parasites in structuring communities come from a wide range of systems. It is more difficult to interpret these isolated reports than it would be if they all came from a single community-type.

Here, we bring together a large amount of published information on parasitism in intertidal communities to highlight the potential influence of parasites on the structure and biodiversity of these communities. Parasites of intertidal animals have been well studied, and an integration of what is currently known can be informative. We first begin by briefly summarising the main features of intertidal ecosystems, and giving an overview of the parasites found in those systems. Then, we examine the known effects of parasites on intertidal hosts. This review focuses only on intertidal macro-invertebrates, and not on the meiofauna or interstitial animals $(<0.5 \mathrm{~mm}$ in dimension), for which little information is available regarding parasitism. Finally, we put this information together in a discussion of the impact of parasitism at the community level.

\section{INTERTIDAL SYSTEMS AT A GLANCE}

Intertidal areas are at the interface between marine and terrestrial habitats (Nybakken, 1993; Bertness, 1999). Although inhabited almost exclusively by 
marine organisms, they are regularly visited by shorebirds and even passerines that feed on intertidal animals. Invertebrates living permanently in the intertidal zone face the greatest temporal variations in environmental conditions of any marine habitat. The action of tides exposes intertidal invertebrates to the air at regular intervals; the tolerance of animals to air exposure and the higher temperatures associated with it can be the major determinant of zonation patterns among the species forming intertidal communities. The upper intertidal, for instance, is inhabited only by the species most resistant to water loss, heat stress, mechanical stress from wave action, and osmotic stress caused by rainfall during low tide. Since many intertidal invertebrates have planktonic larvae, processes controlling larval settlement play a major role in determining the species composition of intertidal communities. The species found in one locality are a subset of the pool of species whose larvae occur in coastal currents. Local conditions, such as wave exposure, the type of substrate and the present benthic community of adults, have a strong influence on whether or not larvae of a given species will establish successfully. Intertidal areas can be classified into different types of habitats according to the predominant substrate; here we will consider rocky shores and soft-sediment flats as the best studied types of intertidal habitats.

\section{Rocky shores}

Both the density and diversity of plants and invertebrates reach high levels on rocky shores, because they usually are bathed in nutrient- and plankton-rich waters and provide a good substrate for algal growth (Bertness, 1999). A striking feature on rocky shores is the marked vertical zonation of the major organisms, resulting in often well-defined horizontal bands populated only by the few species restricted or adapted to this particular intertidal zone (Nybakken, 1993; Bertness, 1999). Physical factors, such as the coastal slope and air exposure time, are of prime importance in determining these zonation patterns, but biological processes are also at work in the structuring of rocky shore communities. Interference competition for attachment space on the rocky substrate is usually intense among species of algae as well as between sessile filter-feeding invertebrates such as mussels and barnacles. Predation, e.g. by starfish, crabs, or gastropods, is also an important structuring factor particularly on the more sheltered shores: the action of predators, and their preferences for certain prey, can prevent one prey species from out-competing others, and will affect the distribution and relative abundances of prey species. Similar effects exist regarding the impact of grazers, such as limpets and littorinid snails, on algae. The interactions of physical factors, competition and predation (or grazing), together with the spatial and temporal variability in larval recruitment, are expected to be the main determinants of community structure and species composition in rocky shore systems (Menge \& Sutherland, 1987; Nybakken, 1993; Navarrete \& Menge, 1996; Bertness, 1999).

\section{Soft-sediment flats}

Unlike rocky shores, soft-sediment intertidal flats can only develop in sheltered areas protected from wave action, such as bays, harbours, lagoons or estuaries. The more protected an area is from the action of waves, the more it tends to accumulate finegrained sediments and organic matter (Nybakken, 1993). There is thus a continuum among softsediment intertidal flats, from mud flats to sand flats, with increasing exposure to waves. Typically, the intertidal slope in these areas is very small, and even at low tide water is retained in interstitial space of the sediment making desiccation a minor problem for soft-bottom invertebrates. For these reasons zonation of organisms is not as pronounced as on the rocky shore. However, the low renewal rate of interstitial water and the action of reducing bacteria in the sediments result in a rapid decrease in oxygen concentration with depth in the sediments, giving rise to anaerobic conditions a few centimetres below the sediment surface. The main plants include a variety of microalgae (diatoms), green and red algae and, usually at lower tidal levels, various seagrasses. Most invertebrates of soft-sediment shores live either freely burrowed into the sediments or construct more or less permanent tubes, relying mainly on surface water for oxygen. They include deposit and suspension feeding polychaetes, bivalves, and crustaceans as well as endobenthic predatory polychaetes and nemertines. Snails that graze algal mats are also common on the surface, in addition to invertebrate predators such as crabs, shrimps and whelks. Because of the accumulation of organic matter on intertidal flats, the density of many of these organisms is often very high. Exploitative competition, however, does not appear to play a major role in the structure of soft-sediment intertidal communities, though it can have more limited effects (Wilson, 1991; Bertness, 1999). Predation, on the other hand, can be very important, especially by fish (rays, flatfish and gobies), epibenthic invertebrates (crabs, shrimps) and shorebirds. Many bird species are migratory and only seasonal visitors of intertidal flats, but during those brief annual visits they can dramatically decrease the densities of many key invertebrates (see e.g. Nybakken, 1993 and references therein). Finally, disturbances that disrupt or destabilise the sediments also have major impacts on soft-sediment communities, whether these disturbances are of abiotic (e.g. storms) or biotic (e.g. burrowing) origins (Bertness, 1999). On the other 
hand, sediment stabilisation through the construction of permanent or semi-permanent burrows and tubes, by polychaetes and amphipods for instance, may also significantly influence the character of the surrounding benthic community (see e.g. Mouritsen, Mouritsen \& Jensen, 1998 and references therein).

\section{Parasites of intertidal organisms}

The present review will focus only on the metazoan parasites of intertidal macro-invertebrates. There are, of course, a wide variety of viruses, bacteria and protozoans that infect intertidal invertebrates (see Sindermann, 1990) and that may impact on community structure; cases involving metazoan parasites, however, should suffice to illustrate the potential importance of parasitism.

Among the metazoans, trematodes are the most common parasites of intertidal animals. Their complex life cycle almost always involves a gastropod, less frequently a bivalve, as first intermediate host, in which larval stages (sporocysts or rediae) engage in the asexual production of cercariae, the next stage in the life cycle. Prevalence of infection in the mollusc first intermediate host is notoriously variable in time and space, and usually relatively low $(<25 \%)$. However, much higher values have regularly been reported (see review in Sousa, 1991; Curtis, this supplement). It must be emphasized that trematode infections in gastropods are ubiquitous : given a large enough sample covering a species' range of habitats, dissections of intertidal gastropods almost always reveal the presence of one or more trematode species. After their release from the first intermediate host, trematode cercariae penetrate and encyst in a second intermediate host, usually another mollusc, a crustacean, a polychaete or a fish. Prevalence in the second intermediate host is usually much higher than in the first intermediate host, often approaching $100 \%$ (see Sousa, 1991). The life cycle of the parasite is completed when the second intermediate host is eaten by a suitable definitive host, most often a shorebird or a fish.

Nematodes are also common parasites of intertidal invertebrates; they use them as intermediate host or as their only host, depending on the parasite species. Larval cestodes and acanthocephalans often use intertidal crustaceans as their intermediate host, their life cycle requiring the ingestion of the crustacean by a suitable fish or bird. Finally, decapod crustaceans in intertidal systems are often infected by parasites that either castrate them or greatly reduce their reproductive output, e.g. nematomorphs, nemertean egg parasites, rhizocephalans, and parasitic isopods (see below). Very few quantitative studies have been performed on these parasites of decapods, but it is clear from the available evidence that they can have dramatic impact on individual host fitness and on host population dynamics.

IMPACT OF PARASITISM ON INTERTIDAL HOSTS

\section{Survival}

By definition any parasite will damage its host to a certain degree, with effects ranging from minor metabolic changes to severe tissue destruction (see Lauckner, 1980, 1983; Price, 1980). Under normal environmental conditions the pathology inflicted may be insignificant in terms of mortality, but when conditions approach the limit to which the host is adapted, reduced survivorship may be the rule. This can be expected to apply in particular to intertidal species that exist at the edge of 'possible', exposed to wide short- as well as long-term fluctuations in temperature, osmotic stress, desiccation and (in softbottom habitats) oxygen conditions. Accordingly, several species of intertidal or estuarine snails show decreased resistance to extreme abiotic conditions when infected by trematodes. The survival of infected periwinkles Littorina littorea is significantly reduced in comparison to control snails when exposed to high temperatures within the natural thermal range (McDaniel, 1969; Lauckner, 1987 a), and a similar effect has been demonstrated in the mud whelk Nassarius reticulatus regarding both high and low temperatures (Tallmark \& Norrgren, 1976). Lower resistance to freezing, osmotic stress, desiccation and/or low oxygen conditions has likewise been shown in an array of trematode-infected hardas well as soft-bottom snail species, including $L$. obtusata, L. saxatilis, Cerithidea californica, Hydrobia neglecta and H. ulvae (Berger \& Kondratenkov, 1974; Sergievsky, Granovich \& Mikhailova, 1986; Sousa \& Gleason, 1989; Jensen, Latama \& Mouritsen, 1996). The synergistic effect of parasites and extreme environmental conditions can also be inferred from a more long-term field experiment on $L$. littorea (Huxham, Raffaelli \& Pike, 1993; Fig. 1). In addition to the unequivocal overall lower survival rate of infected specimens, it appears that the higher mortality among infected snails is largely confined to the winter and summer months, where the abiotic factors also reach their extremes. In addition, Jensen \& Mouritsen (1992) were able to ascribe a $40 \%$ decline in the density of the mud snail H. ulvae in Denmark to the combined effect of infection by microphallid trematodes and unusually high ambient temperatures. The density of infected snails was reduced from more than 10000 to less than 1000 individuals $\mathrm{m}^{-2}$ over a mere five weeks. That trematodes can affect the population dynamics of their snail host significantly is also tentatively supported by data on L. littorea (Lauckner, 1987 a) and demonstrated in a field experiment in the case of C. californica (Lafferty, 1993). 


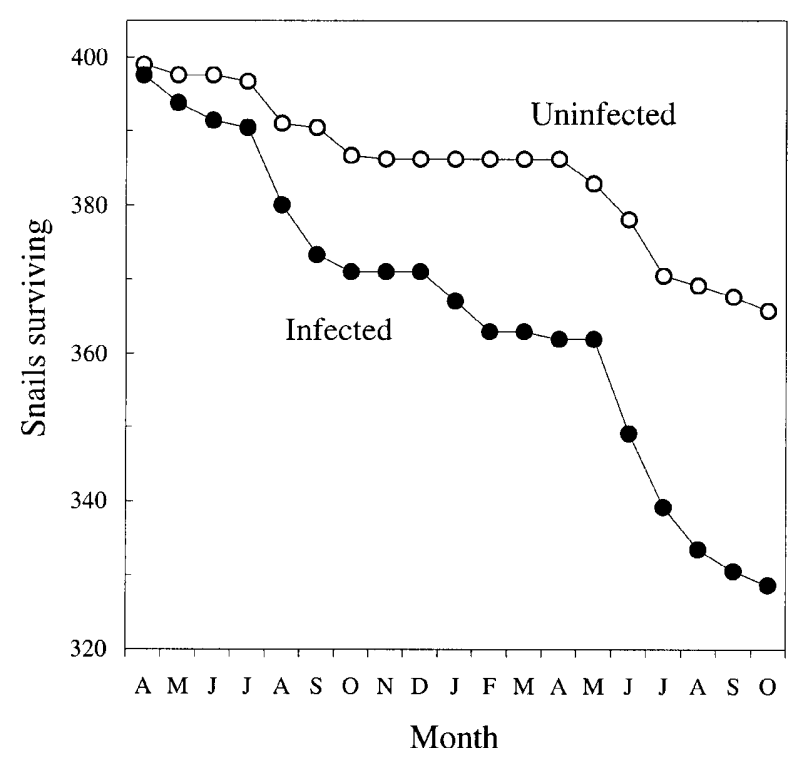

Fig. 1. Mortality of uninfected and trematode-infected periwinkles Littorina littorea caged in situ. Infected specimens were identified on the basis of foot-colour. Subsequent dissections revealed that this method was correct in about $75 \%$ of the cases. (After Huxham et al. 1993.)

Compromised survival of infected individuals is not restricted to gastropods. Bivalves acting either as first or second intermediate host of trematodes experience reduced condition, reduced byssus thread production (in the case of Mytilus edulis), and may be easier to open by predators (Lauckner, 1983; Zwarts, 1991 ; Calvo-Ugarteburu \& McQuaid, 1998). Shellsize/infection intensity relationships in Cerastoderma edule, M. edulis and Tapes philippinarum also suggest increased mortality among both recruits and adults infected by various macroparasites (trematodes, but also cestodes, turbellarians and copepods) (Montaudouin et al. 2000). Similarly, Goater (1993) showed a peaking pattern in mean abundance and in the level of aggregation of the trematode Meiogymnophallus minutus as a function of cockle size (C. edule), suggesting parasite-induced mortality in the older more heavily infected specimens. Jonsson \& André (1992) could even ascribe an event of mass mortality in a population of $C$. edule to infection by the digenean trematode Cercaria cerastodermae I. Experimental work on Cerastoderma supports the above observations, showing significantly reduced survivorship in cockles infected by digenean trematodes (echinostomatids) particularly under environmental stress, such as hypoxia (Lauckner, $1987 b$; Wegeberg \& Jensen, 1999).

Crustaceans are also commonly subject to significant parasite-induced mortality. The small and often very abundant amphipod of north Atlantic intertidal mud flats, Corophium volutator, is the second intermediate host to a range of trematode species of which several have been shown to elevate substantially the mortality rate of the amphipod under laboratory conditions (Mouritsen \& Jensen, 1997; Jensen, Jensen \& Mouritsen, 1998; McCurdy, Forbes \& Boates, $1999 a$; Meissner \& Bick, 1999). That these observations are relevant also in situ can be inferred from field studies in both tidal and nontidal coastal habitats showing impacts of microphallid trematodes on Corophium populations ranging from subtle regulation (Bick, 1994; Meissner, 2001; see Thomas et al. 1995 for a Gammarus example), to major reductions in abundance (Meissner \& Bick, 1997) and even local extinction (Jensen \& Mouritsen, 1992, Fig. 2A). The latter effect coincided with high ambient temperatures that triggered a mass release of the infective cercarial stage from the sympatric population of first intermediate snail hosts. Interestingly, because $C$. volutator can, under certain circumstances, stabilise the substrate by its tube-building activity, the disappearance of the amphipods released sediment erosion that significantly changed the particle size composition of the substrate as well as the topography of the tidal flat (Mouritsen et al. 1998, Fig. 2B-D). Since sediment characteristics are important distributional factors for many infaunal invertebrates (Snelgrove \& Butman, 1994), the changes in the substrate may in part have been responsible for the significant changes in abundance of other macrofaunal species following the amphipod die-off (Jensen \& Mouritsen, 1992; K. N. Mouritsen \& K. T. Jensen, unpublished data).

Other crustaceans also feel the effects of parasites. On rocky shores, the combined effect of infection by microphallid trematodes (Maritrema arenaria) and desiccation has also been suggested to be responsible for observations of sudden shoreward declines in the abundance of the encrusting barnacle Semibalanus balanoides (Carrol, Montgomery \& Hanna, 1990). Prevalence of $M$. arenaria in encrusting barnacles varies among sites but may approach $100 \%$ in the uppermost fringe of the intertidal zone (Irwin \& Irwin, 1980; Mitchell \& Dessi, 1984; Carrol et al. 1990). Among the larger epibenthic predators, crabs are commonly infected by parasites that inflict mortality, in particular at the juvenile stage. For instance, juvenile shore crabs Carcinus maenas appear very sensitive to infection by microphallid trematodes (Lauckner, 1987 b), and a directly transmitted parasitic rhizocephalan has been shown to cause an 8-fold increase in mortality in infected juvenile Rhithropanopeus crabs (Alvarez, Hines \& Reaka-Kudla, 1995). Whereas significant intertidal predators, such as the shore crab (C. maenas) and blue crabs (Callinectes spp.), are rarely found to be infected by rhizocephalans in the intertidal zone, prevalences between 10 and $20 \%$ among adults are common in subtidal samples, occasionally approaching 50 or even $100 \%$ (Wardle \& Tirpak, 1991; Alvarez \& Calderon, 1996; Larzaro-Chavez, Alvarez \& Rosas, 1996; Glenner \& Hoeg, 1997; Mathieson, 

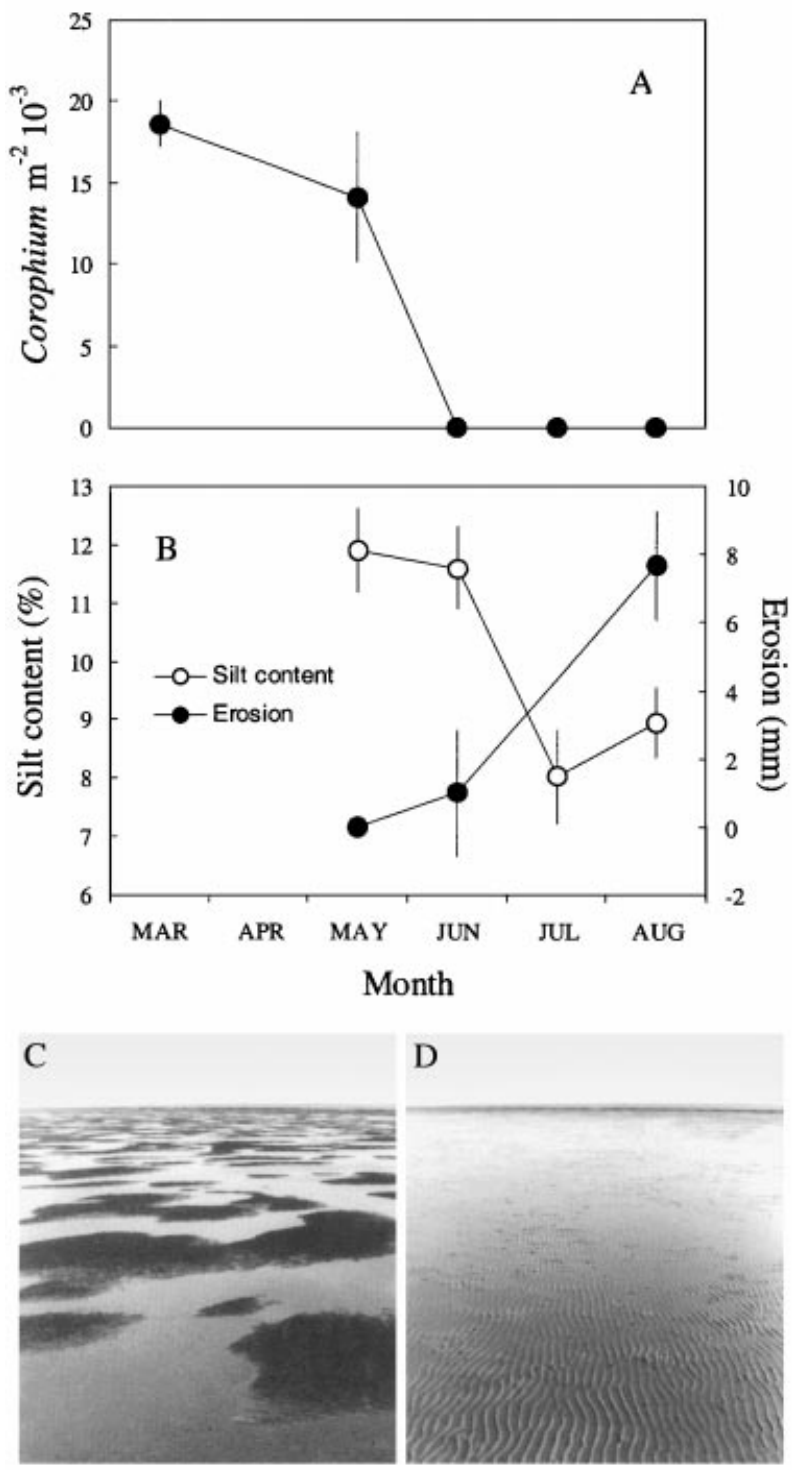

Fig. 2. Extermination of a dense intertidal amphipod population by microphallid trematodes and changes in sediment characteristics and flat topography that followed. (A) Mean density ( \pm s.e.) of Corophium volutator. (B) Mean silt content (i.e. particle diameter $<63 \mu \mathrm{m})(\bigcirc)$ and substrate erosion ( $\mathrm{O}$; the first data point represents first measurement, i.e. the reference level) ( \pm s.E.). (C) The topography of the Corophiumbed prior to the die-off. The amphipods occurred mainly on the emerged areas. (D) The topography of the flat a few months after the disappearance of amphipods. (After Mouritsen et al. 1998.)

Berry \& Kennedy, 1998; Alvarez et al. 1999). Assuming high mortality among infected juveniles, the rhizocephalans may significantly depress the subtidal population of crabs which, in turn, may affect the abundance also in the adjacent intertidal habitat. Little information is available on the effects of other types of parasites on crab survival, but these can be non-negligible. For instance, the relationship between intensity of infection and crab size suggests that acanthocephalans cause mortality in certain
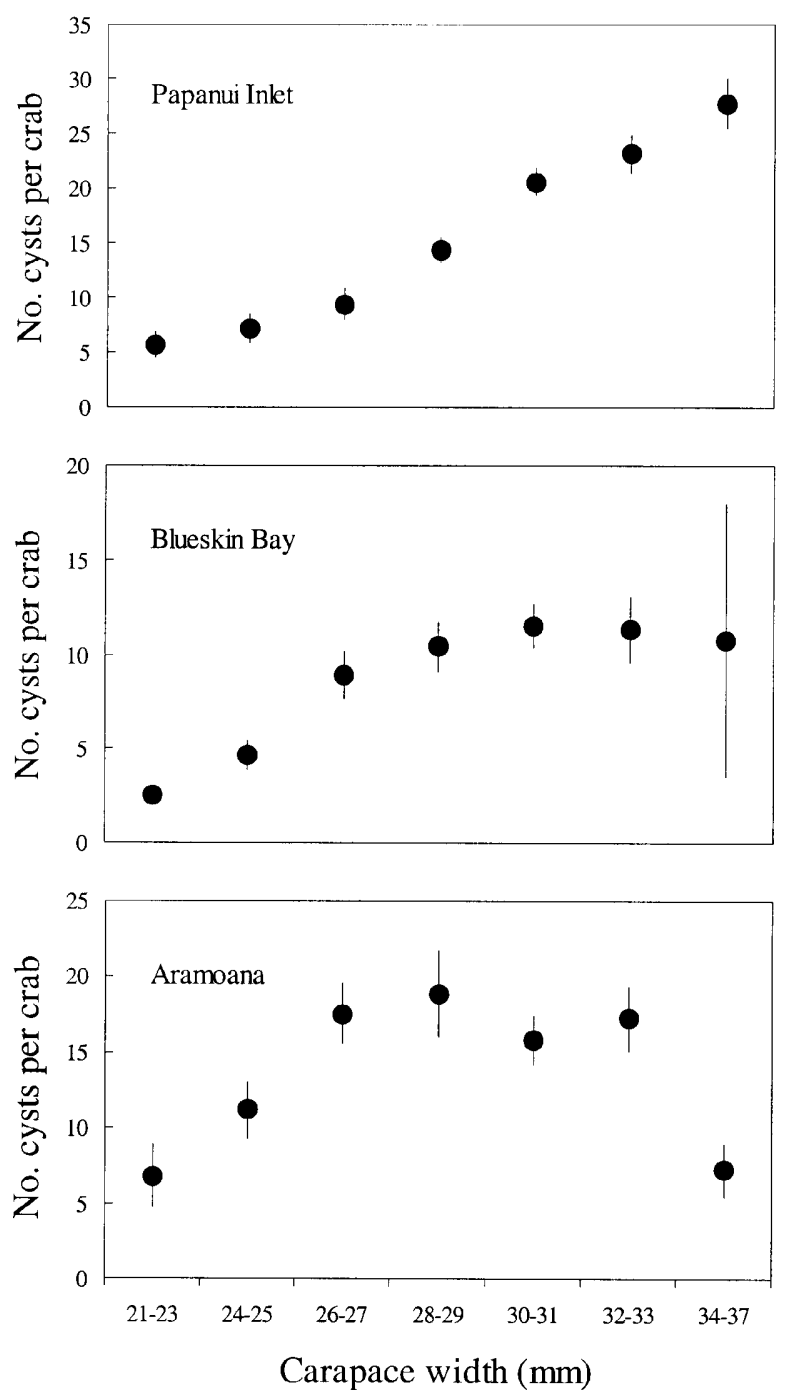

Fig. 3. Acantocephalan-induced mortality in the mud crab Macrophthalmus hirtipes. Mean larvae intensity $( \pm$ s.e.) as a function of size-classes from three different intertidal populations of the South Island, New Zealand. The levelling-out and decrease of mean parasite load in the larger size-classes in Blueskin Bay and at Aramoana, respectively, suggest parasite-induced mortality among the larger and more heavily infected crabs. (Data from Latham \& Poulin, unpublished.)

populations of the mud crab Macrophthalmus hirtipes in New Zealand (Fig. 3).

\section{Reproduction}

Although parasitism, by increasing mortality, may reduce the host population significantly, its effect on host fecundity may be even more severe in terms of population dynamics. Infection by parasites commonly reduces the reproductive output of the host, and in the case of important intertidal genera of molluscs acting as first intermediate hosts to trematodes (e.g. Mytilus, Cerastoderma, Macoma, Hydrobia, Littorina, Cerithidea, Ilyanassa, Nucella), infection inevitably results in partial or complete castration (Feral et al. 1972; Lauckner, 1983; Sousa, 


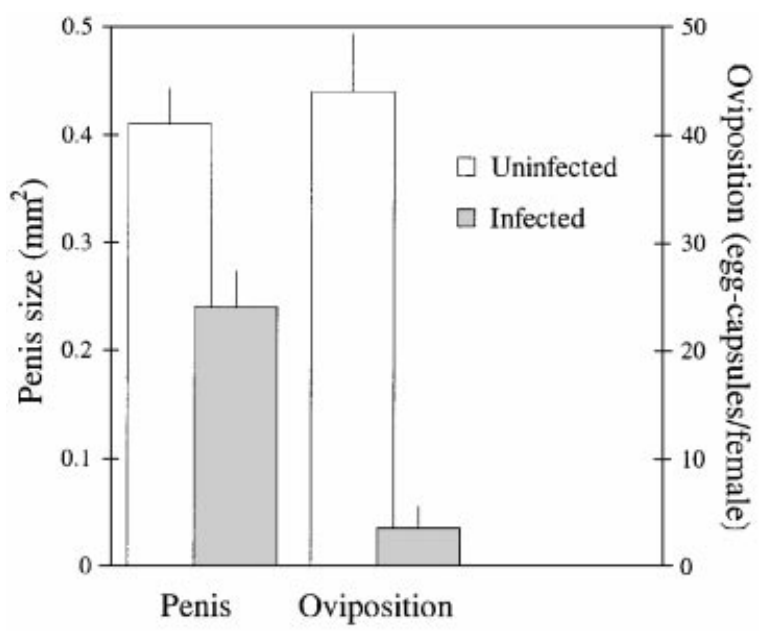

Fig. 4. Parasitic castration of Hydrobia ulvae. Average penis size and oviposition ( \pm s.E.) of uninfected (white columns) and trematode infected (shaded columns) snails. (After Mouritsen \& Jensen, 1994.)

Table 1. Results from statistical analysis testing the difference in growth rate between uninfected and trematode infected hydrobiids from several different snail populations sampled in the White Sea, Denmark and northern Germany. + denotes significantly higher growth rates among infected than uninfected snails $(P<0 \cdot 05)$. NS denotes no statistically significant difference between growth rates. + /NS denotes that the result varied between investigated populations. Growth rate was measured as shell-increment from last growth (winter) interruption line and therefore represent in situ growth rate. (After Gorbushin, 1997.)

\begin{tabular}{lll}
\hline \hline & \multicolumn{2}{l}{ Snail species } \\
\cline { 2 - 3 } & $\begin{array}{l}\text { Hydrobia } \\
\text { ulvae }\end{array}$ & $\begin{array}{l}\text { Hydrobia } \\
\text { ventrosa }\end{array}$ \\
\hline Type of infection & & $\mathrm{NS}$ \\
Notocotylus sp. & $\mathrm{NS}$ & $\mathrm{NS}$ \\
Bonocotyle progenetica & $+/ \mathrm{NS}$ & \\
Himasthla sp. & + & + \\
Cryptocotyle sp. & + & \\
Maritrema subdolum & + & \\
Microphallus claviformis & + & \\
Microphallus pirum & & \\
\hline \hline
\end{tabular}

1983; Pearson \& Cheng, 1985; Lim \& Green, 1991; Coustau et al. 1993; Huxham et al. 1993; Mouritsen \& Jensen, 1994, see Fig. 4). Since the prevalence of trematode infections usually increases with the size/age of the molluscan host, often approaching $100 \%$ in the largest size classes, the impact of the parasites on recruitment may be substantial because the largest individuals in the population also contribute the most to the pool of larvae (Køie, 1975; Hughes \& Answers, 1982; Lauckner, 1980, $1987 a$; Huxham et al. 1993; Curtis, 1997). For host species with pelagic larvae, it is unknown whether this affects the density of recruits locally, but data presented by Lafferty (1993) on C. californica and Sokolova (1995) on L. saxatilis strongly suggest that parasite-induced castration can depress population density in molluscan host species with direct development. Since uninfected individuals of some snail species can engage in copulation activity (i.e. investing time and energy) with infected and hence castrated conspecifics (e.g. L. littorea and Ilyanassa obsoleta; see Saur, 1990; Curtis, this supplement), the impact of castration on recruitment may reach beyond its immediate influence and be more than just proportional to the prevalence of infection in the population.

Trematode infections in molluscs are not the only ones associated with host castration. For instance, infections by nemertean egg parasites can be highly prevalent in certain crab populations, and result in lower reproductive output in infected individuals (Torchin, Lafferty \& Kuris, 1996). More importantly, adult crabs infected by rhizocephalans and adult sessile barnacles infected by the epicarid isopod Hemioniscus balani are also found to be completely castrated (e.g. Blower \& Roughgarden, 1988; Alvarez et al. 1995 and references therein). Since the level of parasitism may attain epizootic proportions (i.e. prevalence far beyond $50 \%$, see earlier references regarding rhizocephalans, and Blower \& Roughgarden, 1989 for Hemioniscus), these parasites may have a profound influence on the population dynamics of their host in certain areas. This may be particularly relevant to the sessile barnacles that require internal cross-fertilisation, and where the risk of infection and barnacle fecundity increase with size (Blower \& Roughgarden, 1987, 1988). As also mentioned above regarding molluscan hosts, because crabs and barnacles have pelagic larvae it may be difficult to identify an impact of the parasites on local host abundance if other regional populations are not affected by parasitism. However, in the case of the direct-developing softbottom amphipod, C. volutator, the apparently trematode-induced lower brood size of infected females is likely to result in lower abundance locally or reduce the rate of colonization in adjacent habitats under high infection intensities (Bick, 1994; McCurdy et al. 1999 a). The mechanism by which the trematodes compromise reproduction in corophiids is unknown, but old females that were newly infected by Gynaecotyla adunca have been observed to abort their young (McCurdy et al. 1999a).

\section{Growth}

Parasites may or may not affect the growth rate of their host. In short-lived intertidal snails, such as Hydrobia spp., castration by trematodes usually results in gigantism (Mouritsen \& Jensen, 1994; Gorbushin, 1997; Gorbushin \& Levakin, 1999; Probst \& Kube, 1999; Table 1), whereas no effect on 


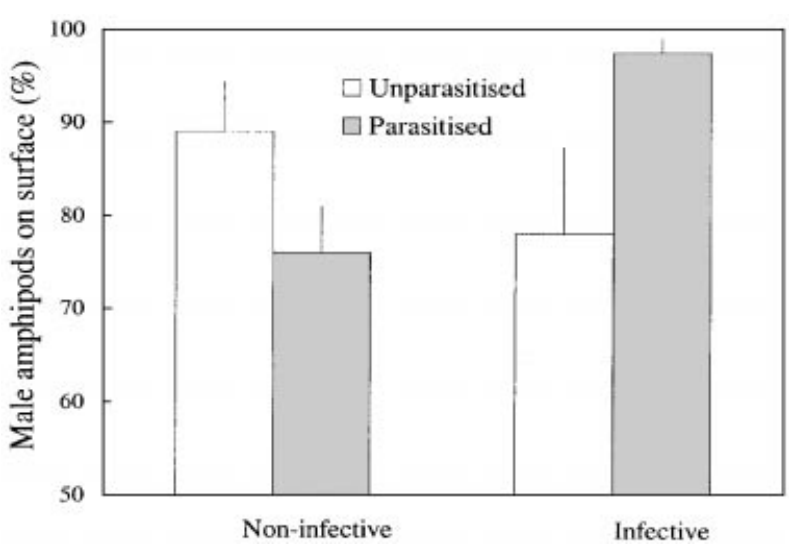

Fig. 5. Parasitic manipulation of male Corophium volutator. Surface activity (mean percent \pm s.E.) of unparasitised (white columns) and parasitised (shaded columns) amphipods, the latter harbouring respectively non-infective and infective larval stages of the nematode Skrjabinoclava morrisoni. (After McCurdy et al. 1999b.)

growth or reduced growth rates have been observed in longer-lived host species, such as Littorina spp., C. californica and I. obsoleta (Sousa, 1983; Lafferty, 1993; Curtis, 1995; Gorbushin \& Levakin, 1999; Mouritsen, Gorbushin \& Jensen, 1999). The qualitative and quantitative effects of trematode infections on snail growth seem to depend on a range of factors other than just the life history characteristics of the host. Most important are the species of trematode involved (i.e. the inflicted level of pathology), the abundance of food and the intensity of exploitative competition experienced by the host (see Mouritsen \& Jensen, 1994; Gorbushin, 1997; Mouritsen et al. 1999). The above statements may apply also to bivalves acting as hosts to digenean trematodes (see Bowers, 1969; Lauckner, 1983 and references therein; Machkevskij, 1988; Lim \& Green, 1991; CalvoUgarteburu \& McQuaid, 1998). Castration by rhizocephalans and epicarid isopods usually results in reduced growth rates in their crustacean host. In rhizocephalan infections, the number of moults and the size increment at each moult may be reduced in infected crabs, eventually causing infected individuals to be significantly smaller than uninfected ones (see Alvarez et al. 1995 and references therein). As a consequence of the more or less interrupted moulting activity, crabs infected by rhizocephalans may support a higher abundance or diversity of fouling organisms (e.g. barnacles and serpulid polychaetes) on their cuticles (Thomas et al. 1999; K. N. Mouritsen \& T. Jensen, unpublished data).

\section{Behaviour}

Parasites commonly alter the behaviour of their hosts either as a side effect of infection or as an adaptive manipulation by the parasite with the purpose of facilitating transmission. In any case, the changed behaviour may result in increased predation pressure on the infected host or affect the way the host species interacts with the remaining benthic community of plants and animals due to its changed spatial distribution. Behavioural effects of infection believed to result from adaptive manipulation include the changed zonation or microhabitat selection of the periwinkles L. saxatilis and L. obtusata infected by microphallid metacercariae, and the dogwhelk Nucella lapillus infected by Parorchis acanthus (Philophthalmidae), that might increase predation by definitive hosts such as gulls and oystercatchers (Feare, 1971; Mikhailova, Granovich \& Sergievsky, 1988; Granovich \& Sergievsky, 1989; McCarthy, Fitzpatrick \& Irwin, 2000). Another example comes from parasite-specific changes in the zonation of $I$. obsoleta that facilitate cercarial transmission to various species of second intermediate amphipod hosts inhabiting different intertidal zones (Curtis, 1987, 1990; McCurdy, Boates \& Forbes, 2000). Surfacing behaviour of otherwise buried soft-bottom hosts, known or assumed to facilitate trophic transmission to shorebirds, has been observed in the mud snail H. ulvae (Huxham, Raffaelli \& Pike, 1995a), in the cockles C. edule (Lauckner, 1984; Jonsson \& André, 1992) and Austrovenus stutchburyi (Thomas \& Poulin, 1998), and in the amphipod C. volutator (Mouritsen \& Jensen, 1997; McCurdy et al. 1999a). And although the crawling behaviour of the tellinid bivalve Macoma balthica on the sediment surface appears natural in this species, trematode infections might enhance the activity (Mouritsen, 1997). The reverse position, closer to the sediment surface, in the bivalve Venerupis aurea infected by Meiogymnophallus fossarum seems, on the other hand, directly parasite induced (Bartoli, 1974, 1976). Among behavioural alternations of hosts following infection that may be simply side effects, there are reports of reduced mobility, changed direction of locomotion and altered zonation in gastropods. Good examples include trematode-infected periwinkles $L$. littorea (Lambert \& Farley, 1968; Williams \& Ellis, 1975), the mud snail H. ulvae (Mouritsen \& Jensen, 1994; Huxham et al. 1995a), the top shells Diloma subrostrata (Miller \& Poulin, 2001) and the mud snail I. obsoleta (Curtis, this supplement). Finally, the mere presence of parasites in the habitat can also have impacts on snail behaviour; for example, the movements of $L$. littorea on the substrate are influenced by the presence of bird droppings and its content of trematode eggs, with the snails apparently trying to avoid infection (Davies \& Knowles, 2001).

Parasites other than trematodes can also affect the behaviour of intertidal invertebrates. For instance, the nematode Skrjabinoclava alters the crawling behaviour of the amphipod $C$. volutator in ways that make it more susceptible to predation by shorebirds (McCurdy, Forbes \& Boates, 1999b; Fig. 5). Acanthocephalans are known as master manipulators of 
their crustacean intermediate hosts, as became apparent from numerous studies on freshwater amphipods and isopods (Moore, 1984). Similar results are likely to be obtained with intertidal species. Some effects on either behaviour or colouration have been observed in crabs, the only intertidal crustaceans in which the impact of acanthocephalans have been investigated (Pulgar et al. 1995; Haye \& Ojeda, 1998; Latham \& Poulin, 2001).

\section{PARASITISM AND INTERTIDAL COMMUNITIES}

What is the impact of these direct effects on host behaviour, growth, reproduction or survival, on the overall structure and diversity of intertidal communities? On the one hand, the effects of parasites on given hosts may have little impact on local larval recruitment, i.e. on the number of larvae of the host species that settle per unit time. High levels of infection may reduce the production of host larvae at one locality, but if for some reason the parasite is not prevalent in adjacent localities, the pool of planktonic larvae available for recruitment will be mostly unaffected. On the other hand, following larval establishment, parasitism could result in reductions in host population size, and in altered distributions of host body sizes. Very few studies have specifically addressed the role of parasitism at the level of community organisation, whether in intertidal systems or in other ecosystems. Here, we will discuss two of the ways, based on whether they have numerical or functional effects on their hosts, in which parasites may affect intertidal communities, trying to integrate the information presented above into scenarios that are plausible without being too speculative.

The first way in which parasites can influence intertidal communities is via their direct effects on host density, mediated by reductions in host survival or reproductive output. If the local abundance of a species declines, we should expect that this would have consequences for its prey, its predators or its competitors. For instance, classical removal/exclusion experiments (e.g. Paine, 1966; Dayton, 1975; Menge, 1976) have shown that the local abundance of a single, 'keystone' species can be the main determinant of the relative abundance and diversity of other organisms in intertidal systems. Key predators can prevent one or more prey species from becoming over-abundant and driving other species to local extinction, especially when they compete for attachment space on rocky substrates. A decrease in predator abundance can allow a few prey species to profit at the expense of others, with the outcome being a reduction in local diversity. The same argument applies to key grazers and the algae on which they feed. Many key predators and grazers in intertidal systems are infected by parasites that reduce their survival or reproduction, and reductions in the local abundance of these key species should be expected to have the sort of consequences outlined above. Clearly, if the species affected by parasitism is a prey instead of a predator, we may also expect that a decrease in its abundance would have consequences for other species: if it becomes scarce, predators would switch to other prey species that would otherwise not be selected. The actual abundance of a host species does not necessarily need to be reduced by parasitism for impacts on other species to manifest themselves: the parasites may simply reduce the activity levels of the host, or cause it to move towards a different microhabitat. As long as the perceived abundance of the host is altered, we can expect community-wide impacts.

The second major way in which parasites may affect intertidal communities is indirectly, via their coincidental effects on habitat variables that matter to other organisms. The process by which certain organisms modulate the availability or quality of resources for other species, by physically changing some component of the habitat, is referred to as ecosystem engineering (Jones, Lawton \& Shachak, 1997). Parasites can either have impacts on existing ecosystem engineers, or act as engineers themselves (Thomas et al. 1999). A prime example of the interaction between parasitism and ecosystem engineering is provided by the marked changes in sediment composition observed on a Danish mud flat following a massive die-off of the amphipod $C$. volutator caused by trematode infections (see Fig. 2). Under normal circumstances, the amphipods help to stabilise the substrate with their tube-building activity. Their sudden extinction from the site allowed rapid sediment erosion that significantly changed the particle size composition of the mud flat (Mouritsen et al. 1998). Because the characteristics of the sediment are major factors determining whether various species of infaunal invertebrates will settle and survive (Snelgrove \& Butman, 1994), the changes in the substrate appear in part responsible for the significant changes in the diversity and relative abundance of other macrofaunal species following the disappearance of the amphipods (Jensen \& Mouritsen, 1992; K. N. Mouritsen \& K. T. Jensen, unpublished data). This is a dramatic illustration of the far-reaching consequences of parasitism in one species mediated by coincidental changes in the physical features of the habitat.

There are other examples of this nature. In softsediment communities, many trematodes impair the burrowing ability of their molluscan host (see above). A parasite-induced increase in the density of bivalves exposed at the surface of the sediments could alter water flow and sediment deposition, thus changing the characteristics of the sediments and the infaunal invertebrates that can become established (see Cummings et al. 1998; Ragnarsson \& Raffaelli, 1999). In addition, the presence of molluscs at the surface of 

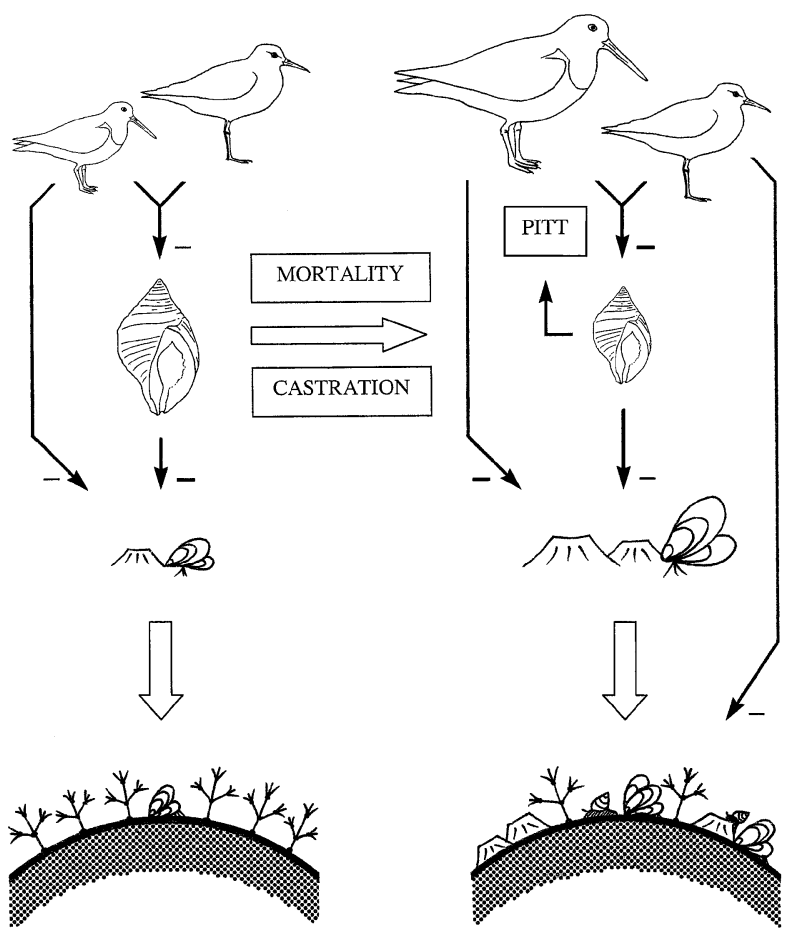

$\mathrm{H}^{\prime}$

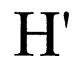

Fig. 6. The predicted appearance of the benthic intertidal community on a hypothetical Nucella dominated rocky shore in the absence and presence of a castrating and pathogenic trematode. Icons from above: oystercatcher and sandpiper; dogwhelk (Nucella); Balanus spp. and Mytilus sp.; macroalgae and littorinids. Arrows with a minus denote negative impact on abundance. Open arrow means 'results in'. Text boxes represent parasite-mediated processes. PITT: parasite increased trophic transmission. $\mathrm{H}^{\prime}$ denote species diversity. Larger or smaller symbols indicate respectively increase or decrease in the given process, value or abundance. See text (scenario I) for other details.

the sediments provides a hard substrate for various plants and invertebrates that would otherwise have no such substrate for attachment in soft-sediment habitats. For example, heavy infections of the trematode Curtuteria australis prevent the cockle $A$. stutchburyi from burrowing $2-3 \mathrm{~cm}$ into the sediments, as healthy cockles do (Thomas \& Poulin, 1998). Several epibiotic, or fouling, organisms use cockle shells as attachment substrates and even compete for space in areas where they are abundant. There is evidence that a species of limpet, which is normally out-competed for space on burrowed cockles by a sea anemone, has a preference for surface cockles, and that its coexistence with the anemone is possible mainly because of the parasitemediated availability of surface cockles (Thomas et al. 1998). Thus the fouling community of the host is not independent of the action of its parasites. This may be true whether or not burrowing is involved. For instance, the proportion of the shell covered by epiphytic algae is greater in snails, H. ulvae, parasitised by trematodes than in uninfected snails (Mouritsen \& Bay, 2000); a possible explanation could be that the defences of snails against fouling algae are compromised by infection. Since hydrobiids, through their action as substrate for germlings, seem important for the development of green algae mats in some soft-bottom intertidal habitats (Schories et al. 2000), and because algal mats significantly affect the abundance and composition of the benthic fauna (Raffaelli, Raven \& Poole, 1998), an interaction between parasitism and fouling defences of the snails may have consequences also for the benthic community surrounding these hosts. As a final example of an indirect effect of parasitism on fouling organisms, the infrequent moulting of crabs infected by rhizocephalans allows greater numbers and a higher diversity of fouling organisms (e.g. barnacles and serpulid polychaetes) to establish on their carapace (Thomas et al. 1999; K. N. Mouritsen \& T. Jensen, unpublished data). In this case, the parasite increases the permanence of a habitat that would normally be too ephemeral to support many epibionts. The point of all these examples is that the impact of parasites on the growth or behaviour of intertidal invertebrates can have a myriad of consequences for the infauna, the epibiotic organisms, or other components of the community; these effects can include major increases as well as decreases in local biodiversity, but they have not been emphasised before simply because they have not been studied.

Based on documented processes acting to shape intertidal communities, and on available information on the impact of parasites on species involved in these processes, it is possible to make specific predictions about what certain well-studied intertidal communities would look like in the presence or absence of parasites.

\section{Scenario I (Fig. 6)}

Consider the mid-intertidal level of a semi-exposed rocky shore recently cleared of sessile organism by ice scouring, for instance. Whelks (Nucella) have, together with a few patches of mussels (Mytilus) and acorn barnacles (e.g. Balanus spp.), survived the winter in crevices and rock pools and now occur abundantly throughout the mid-intertidal. These predatory snails feed preferentially on barnacles and mussels and are in high densities capable of significantly diminishing or even completely eradicating their prey populations (Nybakken, 1993; Carroll \& Highsmith, 1996; Navarrete, 1996; Noda, 1999). Barnacles and mussels themselves are superior to macroalgae as space competitors, but in their absence, the algae will spread into the unoccupied space that eventually develops into a mono-cultural 

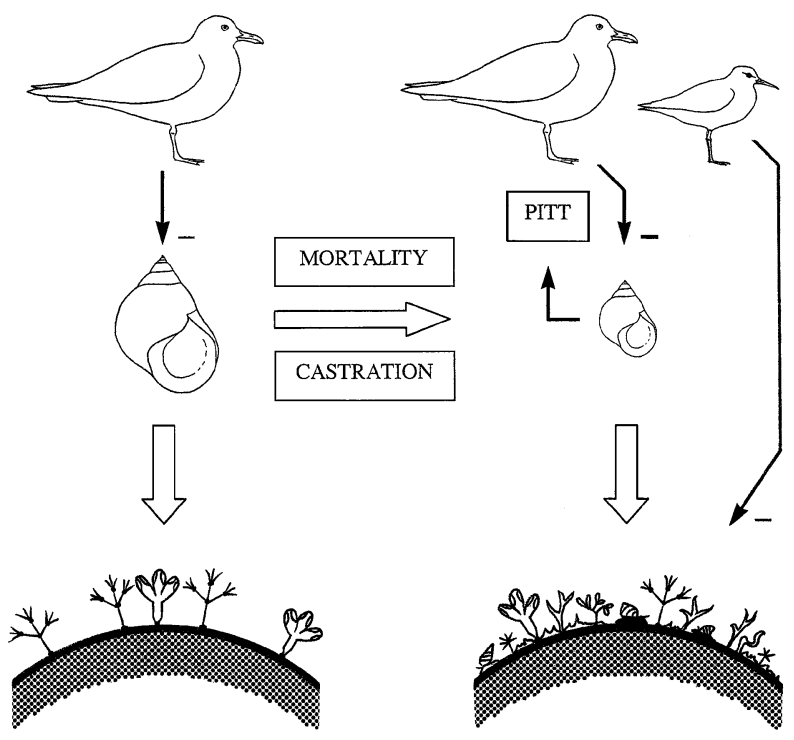

\section{$\mathrm{H}^{\prime}$}

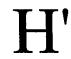

Fig. 7. The predicted appearance of the encrusting algal community on a hypothetical periwinkle (Littorina littorea) dominated rocky shore in the absence and presence of castrating and pathogenic trematodes. Icons from above: Gull and sandpiper; L. littorea; low diversity algal community (left); high diversity algal community and various herbivorous snails other than $L$. littorea (right). See Fig. 7 and text (scenario II) for additional explanations and details.

stand (Nybakken, 1993 and references therein). During this process purple sandpipers and a few oystercatchers visit the site feeding on both the whelks (see Feare, 1970, 1971) and the patches of older mussels left.

Let us introduce a parasite, for instance the castrating trematode Parorchis acanthus that utilizes Nucella as first intermediate host and oystercatchers as final host, the latter reached by trophic transmission (see Feare, 1970, 1971). Since Nucella is ovoviviparous (Hughes, 1986), the parasitic castration will result in a decline in local whelk abundance, reinforced by apparently direct parasiteinduced mortality under the physical stress that prevails on the rock face, and parasite-induced behavioural changes increasing the predation pressure from oystercatchers (Feare, 1971). Released from predatory exclusion due to lower density of whelks, barnacles and mussels now manage to populate the site, which prevents the community succession to proceed into a pure algae culture (see Nybakken, 1993). Because the prevalence of the parasite is moderate (as it is usually the case in first intermediate host populations), and in concert with the increasing number of oystercatchers that visit the site to feed, not only on the now more easily accessible snails but also the more numerous mus- sels, the abundance of whelks is still sufficiently high to keep barnacles and mussels from monopolising the shore. As the dominant space competitors, the mussels will eventually take over the site if not kept in check (see Nybakken, 1993 and references therein). The whelks' predation on the increasing population of barnacles also leaves empty shells scattered throughout the site, paving the way for herbivorous littorinids that, in the case of larger species (e.g. $L$. saxatilis and L. littorea), use them as nursery ground for juveniles, or, in the case of smaller species (e.g. $L$. neritoides and L. neglecta), entirely rely on them as shelter in the mid-intertidal zone (Hughes, 1986; Granovitch \& Sergievsky, 1989). The appearance of the littorinids may in turn keep the sandpipers, known to consume large quantities of the smaller specimens (Faller-Fritsch \& Emson, 1985), attracted to the area.

\section{Scenario II (Fig. 7)}

The herbivorous periwinkle $L$. littorea has been shown to control the species diversity of algae on rock surfaces in a density-dependent manner (Lubchenco, 1978). Under high snail density the algal diversity is lower than when L. littorea is scarce. Moreover, herbivorous snails on rocky shores are likely to face intra- and interspecific exploitative or interference competition that depresses the abundance or, at times, results in exclusion of the inferior species/size class (Underwood, 1976, 1978; Hylleberg \& Christensen, 1978; Brenchley \& Carlton, 1983 ; Faller-Fritsch \& Emson, 1985 ; Petraitis, 1987 ; Yamada \& Mansour, 1987; Chow, 1989). Then consider the mid-intertidal area on a rocky shore, cobble beach or stone jetty that supports an abundant population of, say, L. littorea. As a consequence of the intensive grazing pressure only the most grazingresistant algae species persist, and because of the high level of combined interference and exploitative competition only few con- as well as heterospecific snail-recruits manage to become established on the site, almost completely dominated by larger $L$. littorea specimens. A few scattered gulls are found to feed particularly on the smaller snails available. However, by introducing a range of digenean trematode species using Littorina as first intermediate host and shorebirds as their final host, the snail density decreases due to parasite-induced mortality. Since L. littorea has pelagic larvae, the impact of the inevitable parasitic castration on the abundance of the local snails will at first be undetectable. Later, as the parasites spread along the coastline, the number of recruits that settle on the site may decrease. Because the parasites have made infected snails more vulnerable to bird predation, the gulls in the area have been little affected by the decline in the abundance of L. littorea. For the same reason, however, the number of algal species on the 


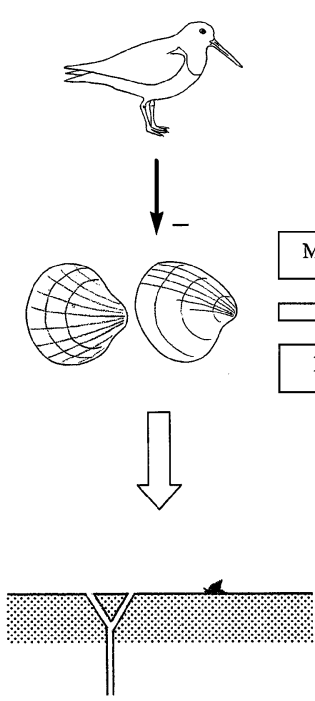

$\mathrm{H}^{\prime}$
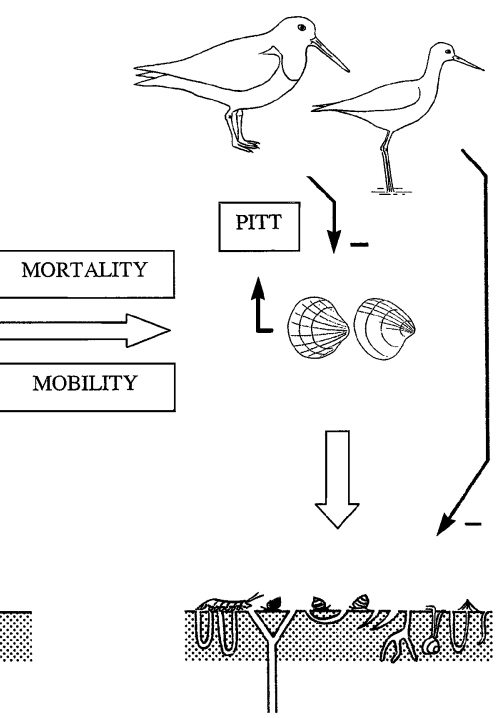

$\mathrm{H}^{\prime}$
Fig. 8. The predicted appearance of the zoobenthic community on a hypothetical soft-sediment flat dominated by the cockle Austrovenus stutchburyi or Cerastoderma edule in the absence and presence of a behaviour-manipulating trematode. Icons from above: oystercatcher and stilt; C. edule (left) and A. stutchburyi (right); burrows from larger and smaller species of polychaetes and amphipods, herbivorous snails and limpets, tellinid bivalve and epibenthic shrimp. See Fig. 7 and text (scenario III) for additional explanations and details.

shore has increased significantly, accompanied by a more diverse assemblage of herbivorous snails (e.g. more L. littorea recruits, L. saxatilis, L. obtusata, or I. obsoleta), profiting either from increased algal diversity used for browsing (see Hughes, 1986; Bertness, 1999), or directly from relaxed competition with L. littorea. As these changes happen, the site becomes more attractive also to smaller bird species (e.g. purple sandpiper and rock pipit) feeding on the increasing number of smaller littorinids (FallerFritsch \& Emson, 1985).

\section{Scenario III (Fig. 8)}

The two cockle species, $C$. edule in the northern hemisphere and $A$. stutchburyi in the south, occur abundantly on tidal flats. In terms of occupied space, they may literally monopolise the upper sediment strata at lower tidal levels (personal observation). Albeit suspension-feeding infaunal organisms, they frequently move, even over longer distances, resulting in substantial disturbance of the upper sediment layer (Richardson, Ibarrola \& Ingham, 1993; Flach, 1996; Whitlatch et al. 1997; K. N. Mouritsen, unpublished data). As a consequence of this biotur- bation, both species have been shown to depress significantly the density of co-occurring infaunal invertebrates or change their relative abundances (Flach, 1996; Whitlatch et al. 1997). Both cockle species are preyed upon by oystercatchers, and are in addition haunted by a range of trematode species that can be expected to affect the cockles' survival rate, fecundity and/or behaviour (see earlier sections and references therein). Among those trematodes Himasthla elongata (and allies), in the case of the European cockle, and $C$. australis, in the case of the New Zealand cockle, are of particular interest. Both are echinostomids that utilize intertidal snails as first intermediate host, cockles as second intermediate host, and cockle-eating shorebirds as final hosts (e.g. Allison, 1979; Lauckner, 1983). In cockles, they specifically infest the foot-tissue causing the foot to become immobilised and stunted which impairs the cockles' ability to move and re-burrow if dislodged to the surface (Lauckner, 1983; Thomas \& Poulin, 1998; Mouritsen, this supplement). Hence, it can be expected that the introduction of echinostomid trematodes to a dense population of cockles will result in increasing densities of other infaunal organisms that profit from (1) unoccupied substrate brought about by the cockles' greater tendency to be dislodged to the surface and an increasing predation pressure from shorebirds feeding preferentially on the surfaced specimens (Lauckner, 1983; Thomas \& Poulin, 1998), and (2), reduced bioturbation from the increasingly immobilised infected population of cockles. This should in turn promote an increasing variety of epifauna, for instance limpets, as previously mentioned, or shrimps, smaller crabs, and benthic fish that feed on the increasingly abundant infaunal polychaetes and amphipods (e.g. Reise, 1985). Eventually, other and smaller species of shorebirds, such as sandpipers, stilts and plovers, may find it worthwhile to feed on the growing population of smaller and more soft-bodied benthic organisms.

\section{Scenario IV}

Through a multitude of processes including grazing, bioturbation, fertilization, and direct interference competition, the largely deposit-feeding mud snail $I$. obsoleta has been shown to impact profoundly on the intertidal benthic community wherever it occurs in reasonable densities. Depending on density, the mud snail may either increase or decrease microalgal productivity and alter the relative abundance of functional groups, which in turn also affect the abundance of nematodes relying on these algae (Nichols \& Robertson, 1979; Connor \& Edgar, 1982; Connor, Teal \& Valiela, 1982). Ilyanassa has also been demonstrated to diminish significantly the density of co-existing oligochaetes, polychaetes, gastropods, bivalves and harpacticoid copepods 
(Levinton \& Stewart, 1982; Hunt, Ambrose \& Peterson, 1987; Dunn, Mullineaux \& Mills, 1999). In particular, the snails can almost completely displace their exploitative competitor Hydrobia totteni to the upper- and lowermost fringes of the intertidal zone, where $I$. obsoleta usually occur in low densities during the productive season (Levinton, Stewart \& Dewitt, 1985). Ilyanassa also acts as first intermediate host to trematodes that change the behaviour of the snail. Seemingly dependent on the vertical distribution of potential second intermediate host on the tidal flat, the infected snails move either toward the high water line or toward the low water line in search for the next host in the parasites' life cycle (Curtis, 1987, 1990; McCurdy et al. 2000). By doing so, the snails' substantial impact on the benthic community can be envisaged to follow in their trails, transforming it accordingly throughout a larger intertidal range than otherwise would have been expected if no parasites were present in the system.

Although the above scenarios necessitate assumptions regarding the physical conditions, the strength of biotic interactions, and the composition of the initial benthic community (for instance, an abundant starfish population under scenario I would likely undermine the ability of whelks to control their common prey population [see Navarrete \& Menge, 1996; Bertness, 1999]), scenarios I-III clearly suggest that parasites retain the potential of increasing the species diversity of the tidal community on all trophic levels. Regarding scenario IV, it is more difficult to make specific predictions. However, it is reasonably safe to expect that the structure of the benthic community will change wherever the infected snails appear. And should such sites be strongly dominated e.g. by amphipod second intermediate hosts, the sediment re-working activity of I. obsoleta may allow for immigration of other infaunal organisms that cause the diversity to increase.

Whether parasites affect intertidal communities directly or indirectly, the magnitude of their impact is unlikely to be constant in time or space. Seasonal fluctuations in recruitment of parasites by intertidal invertebrates have been documented (see review by Lauckner, 1980, 1983). Similarly, the abundance of parasites also varies in space (see Carrol et al. 1990; Sousa, 1991 ; Curtis, this supplement), for a variety of reasons including the local availability of other essential hosts in the parasite's life cycle and physical features of the habitat such as wave exposure. Often, a parasite with a marked effect on host populations in one area will be almost completely absent from another geographical area. There is also spatial variation in parasite infections on much smaller scales. For instance, the precise position of a snail on a mud flat, relative to where shorebirds aggregate and defaecate, can determine its probability of being infected by larval trematodes (e.g. Smith, 2001), creating a mosaic of infection foci in the twodimensional snail habitat. Also, there are often gradients in the intensity or prevalence of trematode infection in more or less sessile invertebrates from the lower to the upper shore (Carrol et al. 1990; Lim \& Green, 1991; Poulin, Steeper \& Miller, 2000). This spatiotemporal variability does not diminish the potential importance of parasitism in the structure of intertidal communities; it simply means that parasitism is a dynamic factor like most other structuring processes.

Parasite species are deeply embedded in a complex network of interactions with the other species in intertidal communities, and ignoring them in studies of community structure can be misleading (Sousa, 1991). Traditional food web models have often focused on energy flows along the different trophic links in the web. Parasites are very rarely, if at all, included in food web models (Marcogliese \& Cone, 1997; Raffaelli, 2000). One practical reason for this may be that ecologists find it easier simply to exclude them; a more scientific reason may be that often energy flows from hosts to parasites are trivial compared to those from prey to predators. The single study that has incorporated parasites in an intertidal food web model has shown that including them changes estimates of various statistics used to summarize food web processes, such as food chain length and linkage density (Huxham, Raffaelli \& Pike, $1995 b$ ). These parameters are often linked with the stability of food webs and ecosystems and their resilience to perturbations, and Huxham et al.'s (1995b) study thus emphasizes the importance of parasitism at the community level. Parasites may not themselves take part in significant energy flows in the food web, but they have huge functional effects on other energy flows and on the species composition of the food web. Their main roles are to directly mediate other trophic or competitive interactions in the systems, or indirectly cause changes to the availability of physical resources (e.g. attachment space) for various organisms. These are the roles documented thus far, but there are likely others. The key importance of other types of symbiotic interactions for community structure has also been recently highlighted (e.g. Stachowicz, 2001), and the time has come to take these suggestions seriously. In the past, the experimental approach has proven fruitful in community studies of intertidal systems, mainly because it is logistically easy to carry out replicated, small-scale, short- or long-term manipulative experiments in these systems (Raffaelli, 2000). Manipulating the abundance of parasites, e.g. by excluding them from certain areas, is logistically more challenging, but it is not unthinkable (Sousa, 1991). Clever solutions to these experimental difficulties, tailored to specific systems, are likely to pave the way toward a better understanding of parasitism and community structure. 


\section{ACKNOWLEDGEMENTS}

We are grateful to Dr Andrey Granovitch, St Petersburg State University, who translated key parts of several of the Russian papers, and to David Latham for access to unpublished data on acanthocephalan infections in crabs. We also wish to acknowledge the referees for useful comments to an earlier draft. The work was supported by The Marsden Foundation (New Zealand) and The Danish Natural Science Research Council (K. N. Mouritsen).

\section{REFERENCES}

ALlison, F. R. (1979). Life cycle of Curtuteria australis n. sp. (Digenea: Echinostomatidae: Himasthlinae), intestinal parasite of the South Island pied oystercatcher. New Zealand Fournal of Zoology 6, 13-20.

Alvarez, F. \& CALDERon, J. (1996). Distribution of Loxothylacus texanus (Cirripedia: Rhizocephala) parasitising crabs of the genus Callinectes in the southwestern Gulf of Mexico. Gulf Research Report 9, 205-210.

Alvarez, F., Garcia, A., robles, R. \& Calderon, J. (1999). Parasitization of Callinectes rathbunae and Callinectes sapidus by the rhizocephalan barnacle Loxothylacus texanus in Alvarado Lagoon, Veracruz, Mexico. Gulf Research Report 11, 15-21.

ALVAREZ, F., HiNes, A. H. \& REAKA-KUDLA, M. L. (1995). The effect of parasitism by the barnacle Loxothylacus panopaei (Gissler) (Cirripedia: Rhizocephala) on growth and survival of the crab Rhithropanopeus harrisii (Gould) (Brachyura: Xanthidae). Fournal of Experimental Marine Ecology and Biology 192, 221-232.

BARTOLI, P. (1974). Recherches sur les Gymnophallidae F. N. Morozov, 1955 (Digenea), parasites d'oiseaux des côtes de Camargue: Systématique, Biologie et Écologie. Ph.D. Dissertation, University of AixMarseille, Aix-Marseille, France.

Bartoli, P. (1976). Modification de la croissance et du comportement de Venerupis aurea parasité par Gymnophallus fossarum P. Bartoli, 1965 (Trematoda, Digenea). Haliotis 7, 23-28.

BERGER, v. G. \& KONDRATENKov, A. P. (1974). The effect of infection of Hydrobia ulvae with larvae of trematodes and its resistance to drying and waterfreshening. Parazitologiya 8, 563-564 (In Russian).

BerTness, M. D. (1999). The Ecology of Atlantic

Shorelines. Sunderland, U.K. Sinauer Associates Inc. BICK, A. (1994). Corophium volutator (Corophiidae:

Amphipoda) as an intermediate host of larval Digenea - an ecological analysis in a coastal region of the southern Baltic. Ophelia 40, 27-36.

Blower, s. M. \& Roughgarden, J. (1987). Population dynamics and parasitic castration: a mathematical model. American Naturalist 129, 730-754.

Blower, s. M. \& Roughgarden, J. (1988). Parasitic castration: host species preferences, size-selectivity and spatial heterogeneity. Oecologia 75, 512-515.

Blower, s. M. \& Roughgarden, J. (1989). Population dynamics and parasitic castration: test of a model. American Naturalist 134, 848-858.
BOWERS, E. A. (1969). Cercaria bucephalopsis haimeana (Lacaze-Duthiers, 1854) (Digenea: Bucephalidae) in cockles, Cardium edule L. in South Wales. Fournal of Natural History 3, 409-422.

Brenchley, G. A. \& CARlton, J. T. (1983). Competitive displacement of native mud snails by introduced periwinkles in the New England intertidal zone. Biological Bulletin (Woods Hole) 165, 543-558.

Calvo-ugarteburu, G. \& McQuaid, C. D. (1998). Parasitism and invasive species: effects of digenetic trematodes on mussels. Marine Ecology Progress Series 169, 149-163.

CARrol, H., MONTGOMERy, W. I. \& HANNA, R. E. B. (1990). Dispersion and abundance of Maritrema arenaria in Semibalanus balanoides in north-east Ireland. Fournal of Helminthology 64, 151-160.

CARroll, M. L. \& Highsmith, R. C. (1996). Role of catastrophic disturbance in mediating Nucella-Mytilus interactions in the Alaskan rocky intertidal. Marine Ecology Progress Series 138, 125-133.

CHOw, v. (1989). Intraspecific competition in a fluctuating population of Littorina plena Gould (Gastropoda: Prosobranchia). Fournal of Experimental Marine Biology and Ecology 130, 147-165.

combes, c. (1996). Parasites, biodiversity and ecosystem stability. Biodiversity and Conservation 5, 953-962.

CONNOR, M. S. \& EDGAR, R. K. (1982). Selective grazing by the mud snail Ilyanassa obsoleta. Oecologia 53, 271-275.

CONNOR, M. S., TEAL, J. M. \& VALIELA, I. (1982). The effect of feeding by mud snails, Ilyanassa obsoleta (Say), on the structure and metabolism of a laboratory benthic algal community. Fournal of Experimental Marine Biology and Ecology 65, 29-45.

Coustau, C., Robbins, I., Delay, B., Renaud, F. \& Mathieu, M. (1993). The parasitic castration of the mussel Mytilus edulis by the trematode parasite Prosorhynchus squamatus: specificity and partial characterization of endogenous and parasite-induced anti-mitotic activities. Comparative Biochemical Physiology 104, 229-233.

Cummings, v. J., Thrush, S. F., Hewitt, J. E. \& TURner, s. J. (1998). The influence of the pinnid bivalve Atrina zelandica (Gray) on benthic macroinvertebrate communities in soft-sediment habitats. Fournal of Experimental Marine Biology and Ecology 228, 227-240.

CURTIS, L. A. (1987). Vertical distribution of an estuarine snail altered by a parasite. Science 235, 1509-1511.

Curtis, L. A. (1990). Parasitism and the movements of intertidal gastropod individuals. Biological Bulletin (Woods Hole) 179, 105-112.

CURTIS, L. A. (1995). Growth, trematode parasitism, and longevity of a long-lived marine gastropod (Ilyanassa obsoleta). Fournal of the Marine Biological Association of the United Kingdom 75, 913-925.

CURTIS, L. A. (1997). Ilyanassa obsoleta (Gastropoda) as a host for trematodes in Delaware estuaries. Fournal of Parasitology 83, 793-803.

DAvies, M. S. \& KNOWLES, A. J. (2001). Effects of trematode parasitism on the behaviour and ecology of a common marine snail (Littorina littorea (L.)). Fournal of Experimental Marine Biology and Ecology 260, 155-167. 
DAYTON, P. K. (1975). Experimental evaluation of ecological dominance in a rocky intertidal algal community. Ecological Monographs 45, 137-159.

DUNN, R., MUllineaux, L. S. \& Mills, S. W. (1999). Resuspension of postlarval soft-shell clams $M y a$ arenaria through disturbance by the mud snail Ilyanassa obsoleta. Marine Ecology Progress Series 180, 223-232.

FALLER-FRITSCH, R. J. \& EMSON, R. H. (1985). Causes and patterns of mortality in Littorina rudis (Maton) in relation to intraspecific variation: a review. In The Ecology of Rocky Coasts (eds. Moore, P. G. \& Seed, R.), pp. 157-177. London; Hodder \& Stoughton.

FEARE, C. J. (1970). Aspects of the ecology of an exposed shore population of dogwhelks Nucella lapillus (L.). Oecologia 5, 1-18.

FEARE, C. J. (1971). Predation of limpets and dogwhelks by oystercatchers. Bird Study 18, 121-129.

Feral, C., BREton, J.-LE. \& STREiff, w. (1972). New observations on parasitic castration in some gastropods. Annales de l'Insitut Michel Pacha 5, 28-40.

FLACH, E. C. (1996). The influence of the cockle Cerastoderma edule, on the macrozoobenthic community of tidal flats in the Wadden Sea. Marine Ecology 17, 87-98.

GLENNER, H. \& HOEG, J. T. (1997). Rhizocephalan parasites and their decapod hosts. Fournal of Shellfish Research 16, 319.

GOATER, C. P. (1993). Population biology of Meiogymnophallus minutus (Trematoda: Gymnophallidae) in cockles from the Exe estuary. Fournal of the Marine Biological Association of the United Kingdom 73, 163-177.

Gorbushin, A. M. (1997). Field evidence of trematodeinduced gigantism in Hydrobia spp. (Gastropoda: Prosobranchia). Fournal of the Marine Biological Association of the United Kingdom 77, 785-800.

Gorbushin, A. M. \& LeVAKin, I. A. (1999). The effect of trematode parthenitae on the growth of Onoba aculeus, Littorina saxatilis and L. obtusata (Gastropoda: Prosobranchia). Fournal of the Marine Biological Association of the United Kingdom 79, 273-279.

GRANOVICH, A. I. \& SERGIEvSKY, S. O. (1989). The use of acorn barnacles' settlements by molluscs Littorina saxatilis (Gastropoda, Prosobranchia) depending on their infestation with parthenites of trematodes. Zoologicheskii Zhurnal 68, 39-47 (In Russian).

HAYE, P. A. \& OJEDA, F. P. (1998). Metabolic and behavioural alterations in the crab Hemigrapsus crenulatus (Milne-Edwards 1837) induced by its acanthocephalan parasite Profilicollis antarcticus (Zdzitowiecki 1985). Fournal of Experimental Marine Biology and Ecology 228, 73-82.

Hudson, P. \& GReEnMan, J. (1998). Competition mediated by parasites: biological and theoretical progress. Trends in Ecology \& Evolution 13, 387-390. Hughes, R. N. (1986). A Functional Biology of Marine Gastropods. London, Croom Helm Ltd.

HUGHES, R. N. \& ANSWERS, P. (1982). Growth, spawning and trematode infection of Littorina littorea (L.) from an exposed shore in North Wales. Fournal of Molluscan Studies 48, 321-330.
HUNT, J. H., AMBrose, W. G. JR \& PETERSON, C. H. (1987). Effects of the gastropod, Ilyanassa obsoleta (Say), and the bivalve, Mercenaria mercenaria (L.), on larval settlement and juvenile recruitment of infauna. Fournal of Experimental Marine Biology and Ecology 108, 229-240.

HUXhaM, M., RAFFAelli, D. \& PIKE, A. (1993). The influence of Cryptocotyle lingua (Digenea: Plathyhelminthes) infections on the survival and fecundity of Littorina littorea (Gastropoda: Prosobranchia); an ecological approach. Fournal of Experimental Marine Biology and Ecology 168. 223-238.

huXhaM, M., Raffaelli, D. \& PIKe, A. (1995a). The effect of larval trematodes on the growth and burrowing behaviour of Hydrobia ulvae (Gastropoda:

Prosobranchia) in the Ythan estuary, north-east Scotland. Fournal of Experimental Marine Biology and Ecology 185, 1-17.

huXham, M., Raffaelli, D. \& PIKe, A. (1995 $b$ ). Parasites and food web patterns. Fournal of Animal Ecology 64, $168-176$.

HYlleberg, J. \& CHRistensen, J. T. (1978). Factors affecting the intra-specific competition and size distribution of the periwinkle Littorina littorea (L.). Natura Futlandica 20, 193-202.

IRWIN, S. W. B. \& IRWIN, B. C. (1980). The distribution of the metacercariae of Maritrema arenaria (Digenea: Microphallidae) in the barnacle Balanus balanoides at three sites on the east coast of Northern Ireland. Fournal of the Marine Biological Association of the United Kingdom 60, 959-962.

Jensen, K. T., Latama, G. \& Mouritsen, K. N. (1996). The effect of larval trematodes on the survival rates of two species of mud snails (Hydrobiidae) experimentally exposed to desiccation, freezing and anoxia. Helgoländer Meeresuntersuchungen 50, 327-335.

JENSEN, K. T. \& MOURitsen, K. N. (1992). Mass mortality in two common soft-bottom invertebrates, Hydrobia ulvae and Corophium volutator - the possible role of trematodes. Helgoländer Meeresuntersuchungen 46, 329-339.

JENSEN, T., JENSEN, K. T. \& MOURITSEN, K. N. (1998). The influence of the trematode Microphallus claviformis on two congeneric intermediate host species (Corophium): infection characteristics and host survival. Fournal of Experimental Marine Biology and Ecology 227, 35-48.

JONES, C. G., LAWTON, J. H. \& SHACHAK, M. (1997). Positive and negative effects of organisms as physical ecosystem engineers. Ecology 78, 1946-1957.

JONSSON, P. R. \& ANDRE, C. (1992). Mass mortality of the bivalve Cerastoderma edule on the Swedish west coast caused by infestation with the digenean trematode Cercaria cerastodermae I. Ophelia 36, 151-157.

KøIE, M. (1975). On the morphology and life history of Opechona bacillaris (Molin, 1859) Looss, 1907

(Trematoda, Lepocreadiidae). Ophelia 13, 63-86.

LAFFERTY, K. D. (1993). Effect of parasitic castration on growth, reproduction and population dynamics of the marine snail Cerithidea californica. Marine Ecology Progress Series 96, 229-237.

LAFFERTY, K. D. (1999). The evolution of trophic transmission. Parasitology Today 15, 111-115. 
LAMBERT, T. C. \& FARLEY, J. (1968). The effect of parasitism by the trematode Cryptocotyle lingua (Creplin) on zonation and winter migration of the common periwinkle, Littorina littorea (L.). Canadian Fournal of Zoology 46, 1139-1147.

LarZaro-Chavez, E., Alvarez, F. \& Rosas, c. (1996). Records of Loxothylacus texanus (Cirripedia: Rhizocephala) parasitising the blue crab Callinectes sapidus in Tamiahua Lagoon, Mexico. Fournal of Crustacean Biology 16, 105-110.

LATHAM, A. D. M. \& POULIN, R. (2001). Effect of acanthocephalan parasites on the behaviour and coloration of the mud crab Macrophthalmus hirtipes (Brachyura: Ocypodidae). Marine Biology 139, 1147-1154.

LAUCKNer, G. (1980). Diseases of Mollusca: Gastropoda. In Diseases of Marine Animals, vol. 1 (ed. Kinne, O.), pp. 311-424. Hamburg, Biologische Anstalt Helgoland.

Lauckner, G. (1983). Diseases of Mollusca: Bivalvia. In Diseases of Marine Animals, vol. 2 (ed. Kinne, O.), pp. 477-961. Hamburg, Biologische Anstalt Helgoland.

LAUCKNER, G. (1984). Impact of trematode parasitism on the fauna of a North Sea tidal flat. Helgoländer Meeresuntersuchungen 37, 185-199.

LAUCKNER, G. (1987a). Ecological effects of larval trematode infestations on littoral marine invertebrate populations. International Fournal for Parasitology 17, 391-398.

LAUCKNER, G. (1987b). Effects of parasites on juvenile Wadden Sea invertebrates. In Proceedings of the 5th International Wadden Sea Symposium (eds. Tougaard, S. \& Asbirk, S.), pp. 103-121. Esbjerg, The National Forest and Nature Agency and the Museum of Fisheries and Shipping.

LEVINTON, J. S. \& STEWART, S. (1982). Marine succession: the effect of two deposit-feeding gastropod species on the population growth of Paranais litoralis Müller 1784 (Oligochaeta). Fournal of Experimental Marine Biology and Ecology 59, 231-241.

Levinton, J. S., STEWART, s. \& DewitT, T. H. (1985). Field and laboratory experiments on interference between Hydrobia totteni and Ilyanassa obsoleta (Gastropoda) and its possible relation to seasonal shifts in vertical mudflat zonation. Marine Ecology Progress Series 22, $53-58$.

LIM, S. L. \& GREEN, R. H. (1991). The relationship between parasite load, crawling behaviour, and growth rate of Macoma balthica (L.) (Mollusca, Pelecypoda) from Hudson Bay, Canada. Canadian Yournal of Zoology 69, 2202-2208.

LuBCHENCO, J. (1978). Plant species diversity in a marine intertidal community: importance of herbivore food preference and algal competitive ability. American Naturalist 112, 23-39.

Machkevskij, v. K. (1988). Effect of Proctoeces maculatus parthenitae on the growth of Mytilus galloprovincialis. Parazitologiya 22, 341-344 (In Russian).

MARCogliese, D. J. \& CONE, D. K. (1997). Food webs: a plea for parasites. Trends in Ecology E Evolution 12, 320-325.

MATHiEson, s., BerRy, A. J. \& KENNEDy, s. (1998). The parasitic rhizocephalan barnacle Sacculina carcini in crabs of the Forth Estuary, Scotland. Fournal of the Marine Biological Association of the United Kingdom 78, 665-667.

MCCARTHY, H. O., FITZPATRICK, S. \& IRWIN, s. W. B.

(2000). A transmissible trematode affects the direction and rhythm of movements in a marine gastropod. Animal Behaviour 59, 1161-1166.

MCCURDY, D. G., BOATES, J. S. \& FORBES, M. R. (2000). Spatial distribution of the intertidal snail Ilyanassa obsoleta in relation to parasitism by two species of trematodes. Canadian Fournal of Zoology 78, 1137-1143.

McCURDY, D. G., FORBES, M. R. \& BOATES, J. S. (1999a). Testing alternative hypotheses for variation in amphipod behaviour and life history in relation to parasitism. International Fournal for Parasitology 29, 1001-1009.

MCCURDY, D. G., FORBES, M. R. \& BOATES, J. S. (1999b). Evidence that the parasitic nematode Skrjabinoclava manipulates host Corophium behavior to increase transmission to the sandpiper, Calidris pusilla. Behavioral Ecology 4, 351-357.

MCDANIEL, J. s. (1969). Littorina littorea: lowered heat tolerance due to Cryptocotyle lingua. Experimental Parasitology 25, 13-15.

MEISSNER, K. (2001). Infestation patterns of microphallid trematodes in Corophium volutator (Amphipoda). Fournal of Sea Research 45, 141-151.

MeIssner, K. \& BICK, A. (1997). Population dynamics and ecoparasitological surveys of Corophium volutator in coastal waters in the Bay of Mecklenburg (southern Baltic Sea). Diseases of Aquatic Organisms 29, 169-179.

MEISSNER, K. \& BICK, A. (1999). Mortality of Corophium volutator (Amphipoda) caused by infestation with Maritrema subdolum (Digenea, Microphallidae) - laboratory studies. Diseases of Aquatic Organisms 35, 47-52.

MENGE, B. A. (1976). Organization of the New England rocky intertidal community: role of predation, competition and environmental heterogeneity. Ecological Monographs 46, 355-393.

Menge, B. A. \& Sutherland, J. P. (1987). Community regulation: variation in disturbance, competition, and predation in relation to environmental stress and recruitment. American Naturalist 130, 730-757.

MIKHAILOVA, N. A., GRANOVICH, A. I. \& SERGIEVSKY, S. O. (1988). Effect of trematodes on the microbiotopical distribution of molluscs Littorina obtusata and $L$. saxatilis. Parazitologiya 22, 398-407 (In Russian).

MILler, A. A. \& POULIN, R. (2001). Parasitism, movements and distribution of the snail Diloma subrostrata (Trochidae) in a soft-sediment intertidal zone. Canadian Fournal of Zoology 79, 2029-2035.

Minchella, D. J. \& SCOTT, M. E. (1991). Parasitism: a cryptic determinant of animal community structure. Trends in Ecology छे Evolution 6, 250-254.

MitChell, J. B. \& DESSI, J. (1984). A note on the distribution of metacercariae of Maritrema arenaria in Balanus balanoides at a site on the north-east coast of England. Fournal of the Marine Biological Association of the United Kingdom 64, 734-735.

MONTAudouin, X. DE, Kisielewski, I., BaChelet, G. \& DESClAUX, C. (2000). A census of macroparasites in an 
intertidal bivalve community, Archachon Bay, France. In National Programme on the Determinism of Recruitment, vol. 23 (eds. Bhaud, M., Nival, P. \& Bachelet, G.), pp. 453-468. Paris, Elsevier.

MOORE, J. (1984). Altered behavioural responses in intermediate hosts: an acanthocephalan parasite strategy. American Naturalist 123, 572-577.

MOURitsen, K. N. (1997). Crawling behaviour in the bivalve Macoma balthica: the parasite-manipulation hypothesis revisited. Oikos 79, 513-520.

MOURITSEN, K. N. \& BAY, G. M. (2000). Fouling of gastropods: a role for parasites? Hydrobiologia 418, 243-246.

MOURitSEN, K. N., Gorbushin, A. \& JENSEN, K. T. (1999). Influence of trematode infections on in situ growth rates of Littorina littorea. Fournal of the Marine Biological Association of the United Kingdom 79, 425-430.

MOURITSEN, K. N. \& JENSEN, K. T. (1994). The enigma of gigantism: effect of larval trematodes on growth, fecundity, egestion and locomotion in Hydrobia ulvae (Pennant) (Gastropoda: Prosobranchia). Fournal of Experimental Marine Biology and Ecology 181, 53-66. Mouritsen, K. N. \& JENSEN, K. T. (1997). Parasite transmission between soft-bottom invertebrates: temperature mediated infection rates and mortality in Corophium volutator. Marine Ecology Progress Series 151, 123-134.

MOURITSEN, K. N., MOURITSEN, L. T. \& JENSEN, K. T. (1998). Changes of topography and sediment characteristics on an intertidal mud-flat following mass-mortality of the amphipod Corophium volutator. Fournal of the Marine Biological Association of the United Kingdom 78, 1167-1180.

NAVARRETE, s. A. (1996). Variable predation: effects of whelks on a mid-intertidal successional community. Ecological Monographs 66, 301-321.

NAVARRETE, S. A. \& MENGE, B. A. (1996). Keystone predation and interaction strength: interactive effects of predators on their main prey. Ecological Monographs 66, 409-429.

NICHOLS, J. A. \& ROBERTSON, J. R. (1979). Field evidence that the eastern mud snail, Ilyanassa obsoleta, influences nematode community structure. Nautilus 93, 44-46.

NODA, T. (1999). Within- and between-patch variability of predation intensity on the mussel Mytilus trossulus Gould on a rocky intertidal shore in Oregon, USA. Ecological Research 14, 193-203.

nybakken, J. W. (1993). Marine Biology: An Ecological Approach. 3rd edn. New York, Harper Collins.

PaINe, R. T. (1966). Food web complexity and species diversity. American Naturalist 100, 65-75.

PEARSON, E. J. \& CHENG, T. C. (1985). Studies on parasitic castration: occurrence of a gametogenesis-inhibiting factor in extract of Zoogonus lasius (Trematoda). Journal of Invertebrate Pathology 46, 239-246.

PETRaitis, P. s. (1987). The effect of the periwinkle Littorina littorea (L.) and of intraspecific competition on growth and survivorship of the limpet Notoacmea testudianalis (Mueller). Fournal of Experimental Marine Biology and Ecology 125, 99-115.

POULIN, R. (1999). The functional importance of parasites in animal communities: many roles at many levels? International Fournal for Parasitology 29, 903-914.

POUlin, R., STEEPER, M. J. \& Miller, A. A. (2000). Nonrandom patterns of host use by the different parasite species exploiting a cockle population. Parasitology 121, 289-295.

PRICE, P. W. (1980). Evolutionary Biology of Parasites. Princeton, Princeton University Press.

PRoBst, s. \& KUBE, J. (1999). Histopathological effects of larval trematode infections in mudsnails and their impact on host growth: what causes gigantism in Hydrobia ventrosa (Gastropoda: Prosobranchia). Fournal of Experimental Marine Biology and Ecology 238, 49-68.

PUlgar, J., ALDANA, M., VERGara, E. \& GEORGENAscimento, M. (1995). La conducta de la jaiba estuarina Hemigrapsus crenulatus (Milne-Edwards 1837) en relación al parasitismo por el acantocefalo Profilicollis antarcticus (Zdzitowiecki 1985) en el sur de Chile. Revista Chilena de Historia Natural 68, $439-450$.

RAFFaElli, D. (2000). Trends in research on shallow water food webs. Fournal of Experimental Marine Biology and Ecology 250, 223-232.

Raffaelli, D. G., Raven, J. A. \& Poole, L. J. (1998). The ecological impact of macroalgal blooms. Oceanographic and Marine Biology Annual Review 36, 97-125.

RAGNARSSON, S. Á. \& RAFFAElli, D. (1999). Effect of the mussel Mytilus edulis L. on the invertebrate fauna of sediments. Fournal of Experimental Biology and Ecology 241, 31-43.

REISE, K. (1985). Tidal Flat Ecology: An Experimental Approach to Species Interactions. Berlin, SpringerVerlag.

RiCARDSON, C. A., IBARrola, I. \& INGHAM, R. J. (1993). Emergence pattern and spatial distribution of the common cockle Cerastoderma edule. Marine Ecology Progress Series 99, 71-81.

SAUR, M. (1990). Mate discrimination in Littorina littorea (L.) and L. saxatilis (Olivi) (Mollusca:

Prosobranchia). Hydrobiologia 193, 261-270.

SChORIES, D., ANibal, J., Chapman, A. S., HERre, E., ISAKSSON, I., LILlEbØ, A. I., PIHL, L., REISE, K., SPRUNG, M. \& THIEL, M. (2000). Flagging greens: hydrobiid snails as substrate for the development of green algal mats (Enteromorpha spp.) on tidal flats of North Atlantic coasts. Marine Ecology Progress Series 199, $127-136$.

SERGIEVSKy, S. O., GRANOVICH, A. I. \& Mikhailova, N. A. (1986). Effect of trematode infection on survival of periwinkles Littorina obtusata and L. saxatilis under the conditions of extremely low salinity. Parazitologiya 20, 202-207 (In Russian).

sindermann, c. J. (1990). Principal Diseases of Marine Fish and Shellfish, Vol. 2. New York, Academic Press. SMITH, N. F. (2001). Spatial heterogeneity in recruitment of larval trematodes to snail intermediate hosts. Oecologia 127, 115-122.

SNelgrove, P. v. R. \& BUtman, C. A. (1994). Animalsediment relationships revisited: cause versus effect. Oceanography and Marine Biology: An Annual Review 32, 111-177.

SOKolova, I. M. (1995). Influence of trematodes on the demography of Littorina saxatilis (Gastropoda: 
Prosobranchia: Littorinidae) in the White Sea. Diseases of Aquatic Organisms 21, 91-101.

sousa, w. P. (1983). Host life history and the effect of parasitic castration on growth: a field study of Cerithidea californica Haldemann (Gastropoda: Prosobranchia) and its trematode parasites. Fournal of Experimental Marine Biology and Ecology 73, 273-296.

SOusA, W. P. (1991). Can models of soft-sediment community structure be complete without parasites? American Zoologist 31, 821-830.

SOUSA, W. P. \& GLEASON, M. (1989). Does parasitic infection compromise host survival under extreme environmental conditions? The case for Cerithidea californica (Gastropoda: Prosobranchia). Oecologia 80, 456-464.

Stachowicz, J. J. (2001). Mutualism, facilitation, and the structure of ecological communities. BioScience 51, 235-246.

TAllmark, B. \& NORRgren, G. (1976). The influence of parasitic trematodes on the ecology of Nassarius reticulatus (L.) in Gullmar Fjord (Sweden). Zoon 4, 149-154.

THOMAS, F. \& POULIN, R. (1998). Manipulation of a mollusc by a trophically transmitted parasite: convergent evolution or phylogenetic inheritance? Parasitology 116, 431-436.

Thomas, F., Poulin, R., De meeus, T., Guegan, J.-F. \& RENAUd, F. (1999). Parasites and ecosystem engineering: what roles could they play? Oikos $\mathbf{8 4}$, 167-171.

Thomas, F., Renaud, F., DE MeEus, T. \& POUlin, R. (1998). Manipulation of host behaviour by parasites: ecosystem engineering in the intertidal zone? Proceedings of the Royal Society of London B 265, 1091-1096.

Thomas, F., Renaud, F., Rousset, F., CEZIlly, F. \& DE MEEUs, T. (1995). Differential mortality of two closely related host species induced by one parasite. Proceedings of the Royal Society of London B 260, 349-352.

TORCHIN, M. E., LAFFERTY, K. D. \& KURIS, A. M. (1996). Infestation of an introduced host, the European green crab, Carcinus maenas, by a symbiotic nemertean egg predator, Carcinonemertes epialti. Fournal of Parasitology 82, 449-453.

UNDERWOOD, A. J. (1976). Food competition between age-classes in the intertidal Neritacean Nerita atramentosa Reeve (Gastropoda: Prosobranchia). Fournal of Experimental Marine Biology and Ecology 23, 145-154.

UNDERWOOD, A. J. (1978). An experimental evaluation of competition between three species of intertidal prosobranch gastropods. Oecologia 33, 185-202.

WARDLE, W. J. \& TIRPAK, A. J. (1991). Occurrence and distribution of an outbreak of infection of Loxothylacus texanus (Rhizocephala) in blue crabs in Galveston Bay, Texas, with special reference to size and coloration of the parasite's external reproductive structures. Fournal of Crustacean Biology 11, 553-560.

WEgEBerG, A. M. \& JENSEN, K. T. (1999). Reduced survivorship of Himasthla (Trematoda, Digenea)infected cockles (Cerastoderma edule) exposed to oxygen depletion. Fournal of Sea Research 42, 325-331.

Whitlatch, R. B., hines, A. H., THRUSh, S. F., HEWitT, J. E. \& Cummings, v. (1997). Benthic faunal responses to variations in patch density and patch size of a suspension-feeding bivalve. Fournal of Experimental Biology and Ecology 216, 171-189.

Williams, I. C. \& ELlis, c. (1975). Movements of the common periwinkle, Littorina littorea (L.), on the Yorkshire coast in winter and the influence of infection with larval Digenea. Fournal of Experimental Biology and Ecology 17, 47-58.

WILSON, W. H. (1991). Competition and predation in marine soft-sediment communities. Annual Review of Ecology and Systematics 21, 221-241.

YAMADA, S. B. \& MANSOUR, R. A. (1987). Growth inhibition of native Littorina saxatilis (Olivi) by introduced L. littorea (L.). Fournal of Experimental Marine Ecology and Biology 105, 187-196.

ZWARTS, L. (1991). Seasonal variation in body weight of the bivalves Macoma balthica, Scrobicularia plana, Mya arenaria and Cerastoderma edule in the Dutch Wadden Sea. Netherlands Fournal of Sea Research 28, 231-245. 